\title{
Investigation and Research on the Love of Contemporary Chinese Homosexuals Based on the "Love Triangle"
}

\author{
Yunlong Jia
}

\author{
Miami herbert business school \&College of Arts and Science \\ University of miami \\ Miami, Florida, US \\ Corresponding author. Email: jiayunlong996@gmail.com
}

\begin{abstract}
Under the shackles of China's long-standing social customs and moral habits, homosexual groups can only live in the marginal corners of mainstream society and have not been treated equally and openly for a long time. This is the case in most countries in the world. The Chinese have always maintained a certain pessimistic idealism towards love. It is only in modern times that they have begun to face up to what love is. People will pursue love instead of just passing on the family. However, the research on gay love in China still has no beginning. Therefore, this article will use Sternberg's love triangle theory to explore the views and needs of the new generation of gay groups in China through questionnaires. The aim of this research is to learn more about the similarities and differences between homosexual and heterosexual love and help gay people to establish a correct outlook on love. The result shows that the kind of love between the same sex perfectly conforms to the the love described in Sternberg's love triangle theory like most of heterosexual people. Contemporary Chinese homosexual groups have always attached importance to the intimate element of love, followed by decision and finally passion. Their demand for intimacy and passion is increasing with age and significantly weakened after entering society and work and began to show an upward trend again until the age of 30 .
\end{abstract}

Keywords: triangle theory, homosexuals, bottom, love, self-identity.

\section{INTRODUCTION}

Homosexuality has always been a controversial topic since ancient times. It wasn't until modern times that it really came into the eyes of people and the public. But in the world, there are still many countries and people who think that this is not a kind of love, but a kind of pathological quirk. But in fact, after carefully reviewing the history of each country, it is not difficult to find the existence of homosexuality. However, few historical countries or religions have a positive attitude towards homosexuality. Among them, only ancient Greece openly held a positive attitude towards homosexuality. The ancient Greeks publicly recognized heterosexuality and homosexuality in their society, and explained the existence of both in mythology[2].

In modern times, the cognition of homosexuality has been popularized and destigmatized under the continuous efforts of people. Homosexuality has been legalized in many regions and countries. China decriminalized homosexuality in 1997 and removed homosexuality from the mental illness diagnostic manual in 2001. However, discrimination still exists in employment, health care and other areas. For example, the "Mental Health Education for College Students", a publicly-selected course textbook of Jinan University classified homosexuality as a psychological disorder of sex [4]. Unfortunately, this is not an isolated case.

This paper aims to test the love situation of contemporary Chinese homosexuals by Sternberg's love triangle theory. According to the analysis of Sternberg's report in 1986, love is composed of three different latitudes of feelings. The first one is intimacy; the second is passion; the third is commitment [1]. The paper is under the scientific and systematic analysis of the collected data. For most Chinese homosexuals, the active party and the passive party may have different needs for the three parts of love. Perhaps the active 
party pays more attention to the passionate part like straight men in love and homosexuality's heavy passive release will have this psychological state and emotional appeal that is biased towards women's love. This paper has great practical significance. Through the research and analysis of this paper, people can understand China's gay people with a scientific and positive attitude.

\section{METHOD}

This paper is based on a survey. The method used in this survey is an online questionnaire designed by a psychological website[5]. There are a total of 45 questions. This questionnaire is based on Sternberg's love triangle theory. According to Sternberg's love triangle theory, there are three parts of love. The first one is intimacy that is a feeling of warm emotional involvement and mutual attachment. The second is passion is about emotional and physical awakening, which can be regarded as most of the motivation in a relationship. The third is commitment, a kind of emotional acquisition from the cognitive and conscious level[1]. And there are fifteen questions set up respectively in the questionnaire, and the corresponding scores are set according to the answers to different questions for a cumulative analysis. Those higher than 80 are considered normal, and those below 80 are considered missing.

This experiment randomly surveyed a total of 63 new-generation homosexuals in China. Three of the data could not be regarded as valid data due to incomplete data and were included in the experimental conclusions. The age span ranges from 15 to 32 years old, with a total of 32 bottoms, eleven tops, and fifteen $0.5 \mathrm{~s}$. There are nine options for each question, from strongly disagree to strongly agree, from one point to nine points. Therefore, the higher the score, the higher the desire and recognition for the corresponding.

According to the love triangle theory, human love relationships can be specifically divided into eight types: no love, liking, infatuated love, empty love, romantic love, compassionate love, fatuous love, consummate love. The author separates different kinds of love by measuring three components of love[3]. Figure 1 shows the experimental details, and the negative sign means the lack or deficiency of ingredients, the positive sign means the existence of ingredients.
Taxonomy of Kinds of Love

\begin{tabular}{lccc}
\hline & \multicolumn{3}{c}{ Component } \\
\cline { 2 - 4 } \multicolumn{1}{c}{ Kind of love } & Intimacy & Passion & $\begin{array}{c}\text { Decision/ } \\
\text { commitment }\end{array}$ \\
\cline { 2 - 4 } Nonlove & - & - & - \\
Liking & + & - & - \\
Infatuated love & - & + & - \\
Empty love & - & - & + \\
Romantic love & + & + & + \\
Companionate love & + & - & + \\
Fatuous love & - & + & + \\
Consummate love & + & + & + \\
\hline
\end{tabular}

Note $+=$ component present; $-=$ component absent. These kinds of love represent limiting cases based on the triangular theory. Most loving relationships will fit between categories, because the various components of love are expressed along continua, not discretely.

Figure 1 Taxonomy of kinds of love

According to Sternberg's love triangle theory above, there are eight kinds of love. If someone have all three components, it is consummate love. (figure 2)

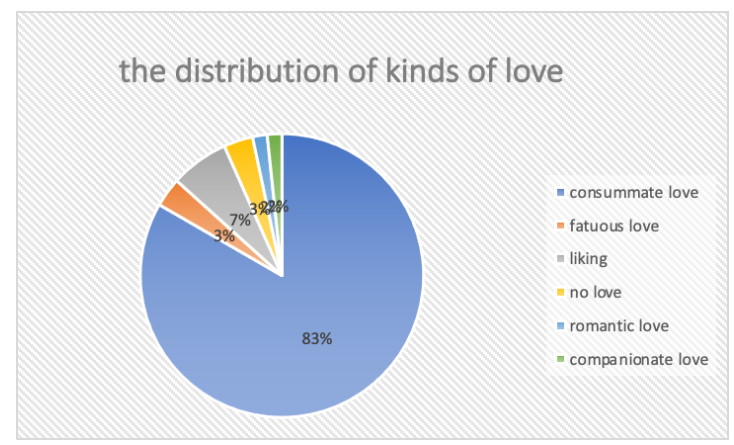

Figure 2 the distribution of kinds of love

After collecting the questionnaire, the result shows that there are sixty valid data including: four liking participants $(6.67 \%)$, two fatuous liking participants (3\%), two no love participants, one compassionate love and one romantic love participant. Most of participants are belong to consummate love.

The results of the sixty participants are classified by age in order to study the overall changes in the three-element demand for love of homosexuals by age. After sorting these data by age, the chart is shown in table 1. These data were divided into four groups: a group aged 15 to 20; a group aged 21 to 25; a group aged 26 to 30 ; a group of 31 to 40 years old. The blue line in the chart is the need for intimacy of the sixty homosexuals tested in different age groups. The orange line in the chart shows the passion needs of the 60 homosexuals tested in different age groups. The gray line in the chart is the needs for decision of the sixty homosexuals tested in different age groups. 
Table 1. The results classified by age

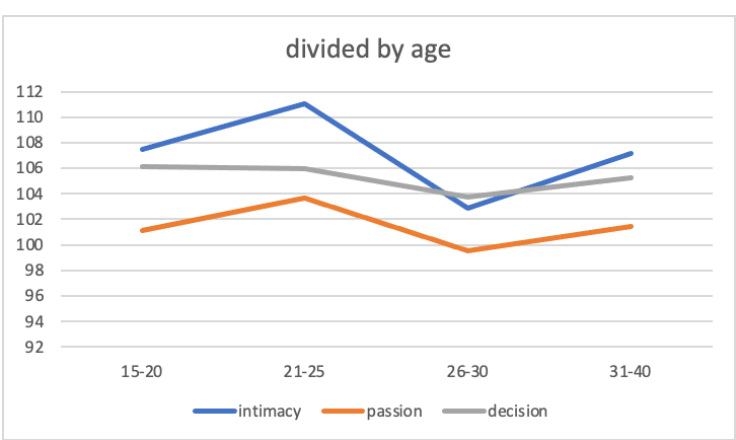

By analyzing the data, the paper can draw a conclusion that the intimacy needs and passion needs of contemporary Chinese homosexuals will be affected by age. Between the ages of 21 and 25, contemporary Chinese homosexuals' demand for intimacy and passion reached the peak, with an average of 110.0625 and 103.625 respectively. After the age of 25 , tremendous changes will occur, and the need for passion and intimacy drops sharply. The average grade decrease from 110.0625 to 102.8571 .

The need for passion has decreased about 4.054 grade; the need for intimacy has decreased 8.21 grade. Looking at the contemporary Chinese homosexual population between 15 and 40 , the need for decision has been relatively stable, but it still start reduced after 21 years old.

There are different sexual identities in homosexuality. They are divided into active parties, which are generally called "top", and passive parties called "bottom". There are also some who want to be both active and passive called "both". Table 2 shows the classification of 60 participants according to their sexual identities. The orange line shows the distribution of the number of bottom in different age groups; the gray line shows the distribution of the number of both in different age groups; the blue line shows the distribution of the number of top in different age groups.

Table 2. report on the sexual identity of the participants

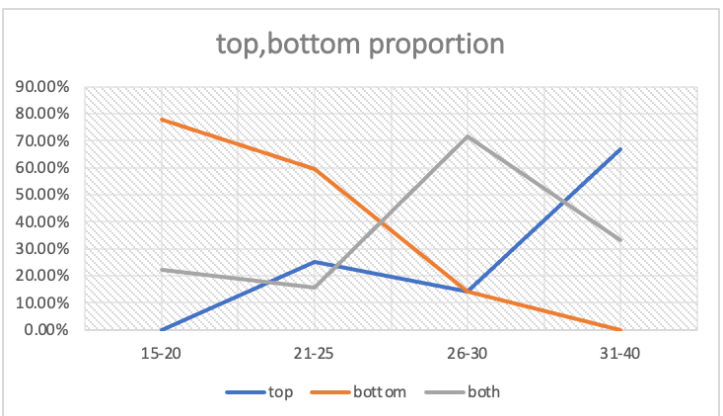

Between the ages of 15 and 20, the proportion of contemporary Chinese homosexuals with top sexual identity is $0 \%$; but after the age of 31 , the proportion of top sexual identity is as high as $66.67 \%$. Between the age of 20 and 30, the number of people who identify as bottom has a decreasing trend. On the contrary, the number of people who identify as top has an increasing trend. Before the age of 30 , the number of normal homosexuals is also showing a rising trend with age.

It has always been believed that the active mental state and needs of homosexuals are more biased towards men in heterosexuals, and vice versa. Table 3 shows that the result of these participants are categorized according to their sexual identity.

Table 3. the classification of gay identity

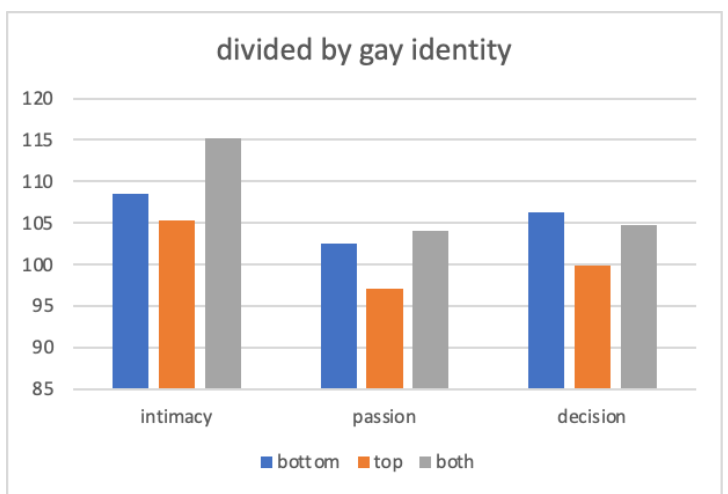

After classifying the 60 surveys' results according to their self-identity. There are 33 bottom data, 15 top data and 11 top data. The contemporary Chinese gay population of Top attribute obviously has lower needs in the three aspects of intimacy, passion, and decision than those of bottom or both. The gap in demand for decision / commitment is the largest, far below the bottom average. The difference of average grade for top and bottom in decision is up to 6.4. In addition, people with a sexual identity of both have a much higher need for intimacy than bottom and top.

\section{DISCUSSION}

With the increasing social and cultural literacy, homosexuality has gradually moved into the public's field of vision. However, there are doubts about homosexuality among the mainstream group or some homosexual people. Among the homosexual group, many people put sex in their lives in the most important position. In recent years, gay dating software has also become popular rapidly; but the stable, long-term and healthy relationship has stagnated. Based on the results of the current questionnaire survey of 60 people, the result points out that homosexual and heterosexual relationships are in the same way, most people are healthy and normal and conform to the ideal model in Sternberg's love triangle theory.

\subsection{The expectations of different gender identities for love}

After the age of 20, contemporary gay groups in China have obviously undergone a huge change in their thinking and needs for the three factors of love. A reasonable speculation about the reasons for this change 
has been made from society, family and career life.The legal age of adulthood in China is 18 years old, and the age of college graduation is 21 to 22 years old. It means that most people will enter the social environment at least after 22 years old, pay more attention to personal and professional development, and gradually reduce their demand for love and sex. It is not until after the age of 30 , after adapting to the work environment, family pressure and social environment, the needs for passion, intimacy and decision-making will gradually rise.

\subsection{Similarities and differences with heterosexual people}

China and other countries in the world have been arguing about the topic of homosexuality. Especially in China, since ancient times, ancient Chinese people have developed under the social benchmark of the union of men and women. Therefore, when it comes to understanding same-sex relationships, it will automatically bring and portray the top. most of people prefer to classify the gay people into two different genders. They think bottom present the role of female and top present the role of man in loving relationship.Therefore, their emotional state should also be related to their needs for the three factors of love. According to Shui yu's research [6], the love outlook of contemporary Chinese college students pointed out that Chinese girls pay more attention to the intimate part of love; Chinese boys pay more attention to passion. However, in the gay status, although bottom is higher than top in the need for intimacy, the gap is not obvious, and top does not want to have a great demand for passion in heterosexual male roles like male characters. It is also worth noting that the appearance of both is much higher than top or bottom in three aspects, which is more in line with the ideal model of Sternberg's love triangle theory.

There are still a lot of mysteries needed to be solved about gay people. For example, why are there more people at the bottom than at the top in Chinese society.

\section{RESULT}

The contemporary Chinese homosexual groups generally have an ideal model of Sternberg's love triangle for their views on love. With the increase of age, from adolescence to university graduation, the Chinese gay community has an increasing demand for intimacy and passion in love. But after stepping into society and work, there is a noticeable weakening of the need for intimacy and passion. It did not show an upward trend until after the age of 30. During this period, the part of the demand for decision in love has not changed much. On the whole, the contemporary gay community in China has always valued the intimacy element of love, followed by decision, and finally the passion.

Based on the results of contemporary Chinese homosexual self-identity recognition, bottom's demand for intimacy, passion and decision in love is higher than top at any time. The crowd is obviously more eager for love. But the people of both have more obvious needs for intimacy, passion and decision in love than top and bottom.

In addition, the ratio of top and bottom among gay people in China also has a certain degree of peculiarities. According to this survey, there are 34 bottom, 11 top and 15 both. The number of people at the bottom is significantly higher than other people. In addition, between the ages of 25 and 30, the number of bottom and top changes in opposite trends. The number of bottom people decreases with age, but the number of both and top is increasing, and the number of both is in the largest proportion is between the ages of 26 and 30 .

\section{CONCLUSION}

This experiment demonstrated that Sternberg's love triangle theory applies not only to heterosexuals but also to homosexuals. In addition, the sexual identity of gay people is open for discussion and further research. In the 60 sets of randomly collected data, homosexual people's identity of their sexual identity is affected by age, and the identity of young people is more likely to be "bottom". The reason behind this is also worthy of further exploration. The data in this trial is more concentrated in the homosexual population between 15 and 25 years old, and less data is collected for the older homosexual population, which may affect the accuracy of the experimental results. And because this experiment collects information through online questionnaires, it cannot guarantee that everyone will take every question very seriously. So there may be interference in some data. Future research needs to pay more attention to the data of homosexuals over the age of 25 and make more in-depth and detailed research on the basis of improving the data.

\section{ACKNOWLEDGMENTS}

Firstly, I would like to show my deepest gratitude to my teachers and professors in my university, who have provided me with valuable guidance in every stage of the writing of this thesis. Further, I would like to thank all my friends and parents for their encouragement and support. Especially for those minority groups, without their help to collect data, it may be difficult to carry out the experiment.Without their enlightening instruction and impressive kindness, I could not have completed the thesis. 


\section{REFERENCES}

[1] Sternberg, Robert J. Construct validation of a triangular love scale. European Journal of Social
Psychology.
1997, 27 (3):
$313-$

335. DOI:10.1002/(SICI)1099-0992(199705)27:3<

313:AID-EJSP824>3.0.CO;2-4.

[2] Janet Shibley Hyde\&John D. DeLamater (2017), Understanding human sexuality, (3),3-4

[3] Sternberg, R. J. (1986). A triangular theory of love. Psycho. Rev., 93.199-35

[4] Ruili Huang, October 29, 2020, China's position on homosexuality has changed, but its textbooks have not yet, The New York times https://www.nytimes.com/2020/10/28/business/inte rnational/china-gay-homosexuality-textbooks-laws uit.htmlga $=2.226939293 .1074892999 .1635276730$ 1727799493.1635276730

[5] Sternberg Love Scale: How deep is your love?,2021,psy525,https://m.psy525.cn/ceshi/8433 1.html

[6] Yu Shui(2015), Investigation and Research on College Students' Love Based on the "Love Triangle", 2015, "Journal of Tongren University" Volume 17, Issue 2. 